\title{
Building energy information: demand and consumption prediction with machine learning models for sustainable and smart cities
}

\author{
Sina Ardabili ${ }^{1}$, Amir Mosavi ${ }^{2,3^{*}}$ and Annamaria R. Varkonyi-Koczy ${ }^{4}$ \\ ${ }^{1}$ Institute of Advanced Studies Koszeg, Koszeg, Hungary \\ ${ }^{2}$ Kalman Kando Faculty of Electrical Engineering, Obuda University, Budapest, \\ Hungary \\ ${ }^{3}$ School of the Built Environment, Oxford Brookes University, Oxford OX3 OBP, UK \\ ${ }^{4}$ Department of Mathematics and Informatics, J. Selye University, Komarno, Slovakia \\ *a.mosavi@brookes.ac.uk
}

\begin{abstract}
Building energy consumption plays an essential role in urban sustainability. The prediction of the energy demand is also of particular importance for developing smart cities and urban planning. Machine learning has recently contributed to the advancement of methods and technologies to predict demand and consumption for building energy systems. This paper presents a state of the art of machine learning models and evaluates the performance of these models. Through a systematic review and a comprehensive taxonomy, the advances of machine learning are carefully investigated and promising models are introduced.
\end{abstract}

Keywords: machine learning, smart cities, IoT, deep learning, big data, soft computing, sustainable urban development, building energy, energy demand, and consumption, sustainable cities 


\section{Nomenclatures}

\begin{tabular}{|c|c|c|c|}
\hline $\begin{array}{l}\text { Generalized boosted regres- } \\
\text { sion }\end{array}$ & GBR & Feed-forward neural networks & FFNN \\
\hline Deep learning & DL & Particle swarm optimization & PSO \\
\hline Artificial neural network & ANN & Random forest & $\mathrm{RF}$ \\
\hline Extreme learning machine & ELM & Non-random two-liquid & NRTL \\
\hline Machine learning & ML & Recurrent neural network & RNN \\
\hline Support vector machine & SVM & Partial least squares & PLS \\
\hline Wavelet neural networks & WNN & Discriminant analysis & $\mathrm{DA}$ \\
\hline Support vector regression & SVR & Principal component analysis & PCA \\
\hline Genetic algorithm & GA & Linear discriminant analysis & LDA \\
\hline Multi layered perceptron & MLP & $\begin{array}{l}\text { Autoregressive integrated mov- } \\
\text { ing average }\end{array}$ & ARIMA \\
\hline Long short-term memory & LSTM & Least-squares & LS \\
\hline Decision tree & DT & Sparse Bayesian & SB \\
\hline $\begin{array}{l}\text { Response surface methodol- } \\
\text { ogy }\end{array}$ & RSM & Multi criteria decision making & $\mathrm{MCDM}$ \\
\hline $\begin{array}{l}\text { Back propagation neural net- } \\
\text { work }\end{array}$ & BPNN & Genetic programming & GP \\
\hline Centroid mean & $\mathrm{CM}$ & Multi linear regression & MLR \\
\hline $\begin{array}{l}\text { Adaptive neuro fuzzy infer- } \\
\text { ence system }\end{array}$ & $\begin{array}{l}\text { ANFI } \\
\text { S }\end{array}$ & $\begin{array}{l}\text { Step-wise Weight Assessment } \\
\text { Ratio Analysis }\end{array}$ & SWARA \\
\hline Analytic network process & ANP & $\begin{array}{l}\text { Multi Objective Optimization by } \\
\text { Ratio Analysis }\end{array}$ & MOORA \\
\hline Radial basis function & RBF & $\begin{array}{l}\text { Nonlinear autoregressive exoge- } \\
\text { nous }\end{array}$ & NARX \\
\hline
\end{tabular}




\section{Introduction}

The energy is one of the essential aspects of smart cities [1]. The sustainability factor of urban development is a direct function of energy production and consumption of every city [2]. The energy consumption of buildings is responsible for a significant amount of energy used in cities [3]. From this perspective, the prediction of demand and consumption is essential in the development of smart cities of the future [4].

Machine learning (ML) has recently well contributed to advancing the accurate and reliable prediction models [5-9]. Literature includes the various application domains and the ML learning methods used in these areas [10-26]. ML methods have shown to outperform most of the conventional modeling techniques considering performance, accuracy, robustness, speed, and computation costs [27-38]. A number of surveys have investigated the usage of ML methods in various application domains [39-43]. However, there is a gap in review studies considering the building energy information for demand and consumption prediction in the era of smart cities, despite the increasing popularity of ML methods. Figure 1 shows the exponential increase in using ML models in this realm within the past decade. Consequently, the contribution of this paper is to investigate the application of novel ML models in shaping the future of smart and sustainable cities in terms of energy.

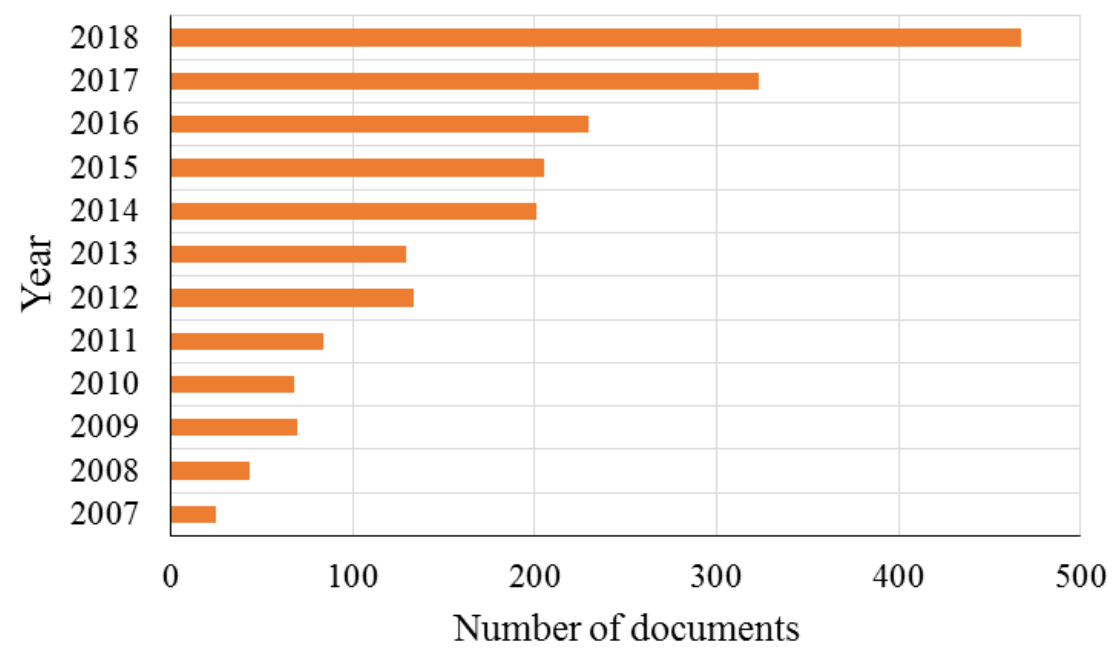

Fig. 1. rapid increase of using ML models in various scientist domains (source: web of science) 


\section{$2 \quad$ Building energy demand prediction}

Prediction of demand in building energy sector is essential for planning and managing energy systems. Table 1 presents top six studied developed by ML methods in building energy demand prediction.

Table 1. Notable ML methods for 2 building energy demand prediction

\begin{tabular}{|c|c|c|c|}
\hline 递 & Contribution & ML method & Keywords \\
\hline [44] & $\begin{array}{l}\text { To employ machine learn- } \\
\text { ing for Quantifying the ef- } \\
\text { fect of landscape composi- } \\
\text { tion and configuration on } \\
\text { urban land surface tempera- } \\
\text { tures }\end{array}$ & $\begin{array}{l}\text { Generalized } \\
\text { boosted regres- } \\
\text { sion }(\mathrm{GBR})\end{array}$ & $\begin{array}{l}\text {-Land surface tempera- } \\
\text { ture } \\
\text {-Machine learning }\end{array}$ \\
\hline [45] & $\begin{array}{l}\text { To present a comprehensive } \\
\text { review about the applica- } \\
\text { tion of machine learning as } \\
\text { a solution in smart build- } \\
\text { ings }\end{array}$ & $\begin{array}{l}\text { ANN, DL, SVM, } \\
\text { GA and SVR }\end{array}$ & $\begin{array}{l}\text {-Internet of Things } \\
\text {-Machine learning }\end{array}$ \\
\hline [46] & $\begin{array}{l}\text { To compare different fore- } \\
\text { casting models for estimat- } \\
\text { ing the natural gas demand }\end{array}$ & $\begin{array}{l}\text { empirical mod- } \\
\text { els, RNN and LR }\end{array}$ & $\begin{array}{l}\text {-Machine learning } \\
\text {-Deep learning }\end{array}$ \\
\hline
\end{tabular}




\begin{tabular}{|c|c|c|c|}
\hline [47] & $\begin{array}{l}\text { To employ different ma- } \\
\text { chine learning methods for } \\
\text { Building Performance Sim- } \\
\text { ulation }\end{array}$ & ANN, LSTM & $\begin{array}{l}\text {-Deep learning } \\
\text {-Machine learning }\end{array}$ \\
\hline [48] & $\begin{array}{l}\text { To present a comprehensive } \\
\text { state of the art of machine } \\
\text { leaning methods for the } \\
\text { prediction of building en- } \\
\text { ergy demand }\end{array}$ & $\begin{array}{l}\text { ANN and SVM } \\
\text { based machine } \\
\text { learning methods }\end{array}$ & $\begin{array}{l}\text {-Machine leaning } \\
\text {-Building energy de- } \\
\text { mand }\end{array}$ \\
\hline [49] & $\begin{array}{l}\text { To present a hybrid ensem- } \\
\text { ble method to increase the } \\
\text { accuracy of load demand } \\
\text { estimation of PV for build- } \\
\text { ing energy sector }\end{array}$ & $\begin{array}{l}\text { Single and hybrid } \\
\text { machine learning } \\
\text { methods }\end{array}$ & $\begin{array}{l}\text {-Machine learning } \\
\text {-Ensemble method }\end{array}$ \\
\hline
\end{tabular}

Osborne and Alvares-Sanches [44] developed an innovative approach in the presence of machine learning technique (GBR) for Quantifying the effect of landscape composition and configuration on urban land surface temperatures. Based on findings of the study, GBR could successfully predict land surface temperatures with a high correlation coefficient (0.956) using 102,935 data.

Djenouri et al. [45] presented a comprehensive state of the art about the application of ML methods in buildings. ML has been employed as solution for occupants and energy or devices. ML can be used as a multi-disciplinary solution for building purposes but in general the type and the size of the building are main factors for considering 
the effectiveness of ML method. But the use of ML methods can be more successful in energy demand purposes in buildings by developing innovative approaches. Hribar et al. [46] developed a study for evaluating the forecasting capabilities of different methods including empirical, deep learning and LR models for the prediction of natural gas demand in the presence of daily and hourly datasets. All the methods have been employed in their single form. Evaluations have been performed by the use of MAE and MAPE factors. Based on results deep learning method have the best performance (with MAE 1.06 and 18.3 for hourly and daily datasets, respectively) compared with that of the other techniques.

Singaravel et al. [47] employed ANN while comparing with single, two and three layer LSTM method for the estimation of building sustainability. Machine learning methods can play an important role in reducing the processing time and increasing the sustainability by increasing the model accuracy. Comparing the accuracy values of models for the prediction have been performed by employing determination coefficient values. Based on results all of methods could successfully cope with the prediction task but two layered LSTM method have the best performance compared with others. Ahmad et al. [48] provided a comprehensive state of the art of the machine learning based prediction models for the estimation of building energy demand sector. In general methods have been divided into two main categories including ANN and SVM based machine learning methods as the most frequently used methods in this field of science. This paper also indicated the importance of machine learning methods in the sustainability of buildings energy demand. SVM based methods provided a higher accuracy compared with that of the ANN based methods.

Reza et al. [49] developed a novel hybrid ensemble method including neural ensemble, Bayesian model and wavelet transform method for the prediction of PV performance in the building energy demand sector. This method has been developed by comparing different single and hybrid machine learning techniques in the term of the normalized root mean square error. This study wants to emphasize on the importance of 
the hybrid methods over the single methods. The proposed hybrid method could successfully estimate the demand forecasting factors and increased the accuracy of the model significantly.

Table 2 present a brief comparison about the accuracy, reliability and sustainability of methods developed for forecasting the energy demand in building sector. Accuracy factor has been generated from the performance factors related to the training step and reliability has been generated from the performance factors related to the testing step. But, sustainability was a little difference and has been generated by comparing reliability, accuracy, processing time and other factors which have been considered by results of the reviewed articles.

Table 2. the comparison results of methods for energy demand in building sector

\begin{tabular}{|l|l|c|c|c|c|}
\hline Method & Application & Accuracy & Reliability & $\begin{array}{l}\text { Sustainabil- } \\
\text { ity }\end{array}$ & $\begin{array}{l}\text { Refer- } \\
\text { ence }\end{array}$ \\
\hline GBR & Regression & ++ & + & +++ & {$[44]$} \\
\hline ANN & $\begin{array}{l}\text { Classifica- } \\
\text { tion }\end{array}$ & + & + & + & {$[45]$} \\
\hline Regression & Classifica- & ++ & ++ & + & {$[45]$} \\
\hline tion & Regression & & & & \\
\hline
\end{tabular}




\begin{tabular}{|c|c|c|c|c|c|}
\hline DL & $\begin{array}{l}\text { Classifica- } \\
\text { tion } \\
\text { Regression }\end{array}$ & +++ & +++ & +++ & [45] \\
\hline $\begin{array}{l}\text { Hybrid } \\
\text { ML }\end{array}$ & $\begin{array}{l}\text { Classifica- } \\
\text { tion } \\
\text { Regression }\end{array}$ & +++ & ++ & ++ & [45] \\
\hline RNN & Regression & +++ & +++ & +++ & [46] \\
\hline LR & Regression & + & + & + & [46] \\
\hline LSTM & Simulation & +++ & ++ & ++ & [47] \\
\hline ANN & Simulation & ++ & + & + & [47] \\
\hline $\begin{array}{l}\text { ANN- } \\
\text { based }\end{array}$ & Regression & + & + & + & [48] \\
\hline $\begin{array}{l}\text { SVM- } \\
\text { based }\end{array}$ & Regression & ++ & ++ & ++ & [48] \\
\hline BPNN & Regression & - & - & - & [49] \\
\hline ARIMA & Regression & + & + & + & [49] \\
\hline
\end{tabular}




\begin{tabular}{|l|l|l|l|l|l|}
\hline RBF-PSO & Regression & + & + & + & [49] \\
\hline FNN-PSO & Regression & ++ & + & + & [49] \\
\hline WT- & Regression & + & - & - & [49] \\
BPNN & & + & & + & [49] \\
\hline WT- & Regression & + & + & + & {$[49]$} \\
ARIMA & & & & + & \\
\hline WT-FNN- & Regression & ++ & ++ & & \\
\hline
\end{tabular}

\section{$3 \quad$ Building energy consumption prediction}

Building energy consumption is important as much as the importance of building energy demand. Prediction of energy consumption in building energy sector can be one of the main steps for reaching the sustainable buildings and is essential for planning and managing of energy systems. Table 3 presents top six studied developed by ML methods in building energy consumption prediction.

Table 3. Notable ML methods for 2 building energy consumption prediction

\begin{tabular}{|c|c|c|c|}
\hline 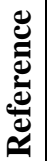 & Contribution & $\begin{array}{l}\text { ML } \\
\text { method }\end{array}$ & keywords \\
\hline
\end{tabular}




\begin{tabular}{|c|c|c|c|}
\hline [50] & $\begin{array}{l}\text { To present a robust artificial neural net- } \\
\text { work to explore complex building energy } \\
\text { consumption data which have been gen- } \\
\text { erated from the simulation-Based Multi- } \\
\text { Objective Optimization model }\end{array}$ & ANN & $\begin{array}{l}\text {-Energy con- } \\
\text { sumption } \\
\text {-Machine learn- } \\
\text { ing }\end{array}$ \\
\hline [51] & $\begin{array}{l}\text { To develop an accurate machine learning } \\
\text { method for energy prediction in buildings } \\
\text { using data generated from internet of } \\
\text { things technology }\end{array}$ & $\begin{array}{l}\text { MLP, } \\
\text { LR,RF, } \\
\text { SVM and } \\
\text { GBM }\end{array}$ & $\begin{array}{l}\text {-Internet of } \\
\text { things } \\
\text {-Machine learn- } \\
\text { ing }\end{array}$ \\
\hline [52] & $\begin{array}{l}\text { To develop a long short term memory } \\
\text { (LSTM) network to predict the energy } \\
\text { consumers' behaviour based on their re- } \\
\text { cent energy consumptions }\end{array}$ & LSTM & $\begin{array}{l}\text {-Machine learn- } \\
\text { ing; } \\
\text {-Smart grid }\end{array}$ \\
\hline [53] & $\begin{array}{l}\text { To develop an innovative hybrid deep } \\
\text { learning method for the prediction of en- } \\
\text { ergy consumption in buildings }\end{array}$ & $\begin{array}{l}\text { Hybrid } \\
\text { LSTM- } \\
\text { GA }\end{array}$ & $\begin{array}{l}\text {-Deep learning } \\
\text {-Machine learn- } \\
\text { ing }\end{array}$ \\
\hline [54] & $\begin{array}{l}\text { To develop a comprehensive survey } \\
\text { about different machine learning methods } \\
\text { developed for the prediction of energy } \\
\text { consumption in buildings }\end{array}$ & $\begin{array}{l}\text { Single, } \\
\text { hybrid and } \\
\text { ensemble } \\
\text { machine } \\
\text { learning } \\
\text { methods }\end{array}$ & $\begin{array}{l}\text {-Data mining } \\
\text {-Machine learn- } \\
\text { ing }\end{array}$ \\
\hline
\end{tabular}




\begin{tabular}{|l|l|l|l|} 
I55] & $\begin{array}{l}\text { In order to develop machine learning } \\
\text { methods for the prediction of energy load } \\
\text { in building sectors. }\end{array}$ & $\begin{array}{l}\text { SVM and } \\
\text { NARX- }\end{array}$ & -Machine learn- \\
RNN & -Deep learning \\
\hline
\end{tabular}

Sharif and Hammad [50] developed a robust ANN method to explore complex building energy consumption data which have been generated from the simulation-Based Multi-Objective Optimization model. In fact, this study focuses on developing an accurate prediction method for the energy consumption of buildings. Evaluating of results indicated that the developed ANN method benefits less time consuming as well as high accuracy, which increases the sustainability of the developed method.

Chammas et al. [51] developed a study for the prediction of the energy consumption in buildings using data generated from the IoT technology embedded in buildings. The proposed method is a prediction model based on MLP while comparing with LR, SVM, GBM, and random forest. Methods have been compared in terms of determination coefficient, MAPE, and RMSE. Dataset for the training process was separated into three categories (no light, no date, and weather only) for finding the effective variables on the modelling process. Based on the results, eliminating lights data have an essential effect on increasing the accuracy of the target model. The developed MLP model has a higher determination coefficient and a lower RMSE and MAPE compared with that for other methods.

Fenza et al. [52] developed a LSTM method for the prediction of consumers' behaviors in the term of energy consumption. Time series data have been employed in order to develop the target network. Results have been evaluated using RMSE factor. Based on the results, the proposed method has successfully cop with the task as well as providing the required sustainability for the prediction phase. Almalaq and Zhang [53] developed an innovative prediction model for the estimation of energy consumption in build- 
ings using LSTM and optimizing its parameters by GA methodology to take an evolutionary DL method. The evaluation phase for this study has been performed by the use of datasets related to residential and commercial buildings. Results indicated that the hybrid methods which take an evolutionary DL method present an accurate and sustainable method for the prediction of energy consumption in buildings over the DL methods.

Chou and Tran [54] developed a comprehensive survey for studying different machine learning techniques developed for the prediction of energy consumption in building sectors. Methods have been categorized into three main categories, including single, hybrid, and ensemble machine learning methods. Methods have been compared in terms of performance factors and sustainability index. Results indicated that in the case of using single and ensemble methods, ANN-based methods have the best prediction performance, but in the case of using hybrid methods, SVM based methods could present the best performance. In general, hybrid methods is the proposed method from the viewpoint of accuracy and sustainability.

Koschwitz et al. [55] developed predictive models in order to estimate the building energy load. The target models include the RBF based SVM and Nonlinear Autoregressive Exogenous Recurrent Neural Networks which have been developed by the historical data from residential buildings in Germany. Based on the results, NARX-RNN provided higher performance and sustainability in comparison with those for the SVM method. Table 4 present a brief comparison of the accuracy, reliability, and sustainability of methods developed for forecasting the energy consumption in the building sector.

Table 4. the comparison results of methods for energy consumption in the building sector 


\begin{tabular}{|c|c|c|c|c|c|}
\hline method & $\begin{array}{l}\text { Applica- } \\
\text { tion }\end{array}$ & $\begin{array}{l}\text { Accu- } \\
\text { racy }\end{array}$ & Reliability & Sustainability & $\begin{array}{l}\text { Refer- } \\
\text { ence }\end{array}$ \\
\hline ANN & $\begin{array}{l}\text { Regres- } \\
\text { sion }\end{array}$ & ++ & ++ & ++ & [50] \\
\hline MLP & $\begin{array}{l}\text { Regres- } \\
\text { sion }\end{array}$ & ++ & ++ & ++ & [51] \\
\hline LR & $\begin{array}{l}\text { Regres- } \\
\text { sion }\end{array}$ & -- & -- & -- & [51] \\
\hline SVM & $\begin{array}{l}\text { Regres- } \\
\text { sion }\end{array}$ & + & + & + & [51] \\
\hline GBM & $\begin{array}{l}\text { Regres- } \\
\text { sion }\end{array}$ & + & + & + & [51] \\
\hline $\mathrm{RF}$ & $\begin{array}{l}\text { Regres- } \\
\text { sion }\end{array}$ & + & + & + & [51] \\
\hline LSTM & $\begin{array}{l}\text { Regres- } \\
\text { sion }\end{array}$ & +++ & +++ & +++ & [52] \\
\hline LSTM-GA & $\begin{array}{l}\text { Regres- } \\
\text { sion }\end{array}$ & +++ & +++ & +++ & [53] \\
\hline
\end{tabular}




\begin{tabular}{|l|l|l|l|l|l|}
\hline $\begin{array}{l}\text { Single-ANN } \\
\text { based }\end{array}$ & $\begin{array}{l}\text { Regres- } \\
\text { sion }\end{array}$ & ++ & ++ & ++ & {$[54]$} \\
\hline $\begin{array}{l}\text { Hybrid- } \\
\text { ANN based }\end{array}$ & $\begin{array}{l}\text { Regres- } \\
\text { sion }\end{array}$ & +++ & ++ & ++ & {$[54]$} \\
\hline $\begin{array}{l}\text { Ensemble- } \\
\text { ANN based }\end{array}$ & $\begin{array}{l}\text { Regres- } \\
\text { sion }\end{array}$ & ++ & ++ & ++ & {$[54]$} \\
\hline $\begin{array}{l}\text { Single-SVM } \\
\text { based }\end{array}$ & $\begin{array}{l}\text { Regres- } \\
\text { sion }\end{array}$ & ++ & ++ & ++ & {$[54]$} \\
\hline $\begin{array}{l}\text { Hybrid- } \\
\text { SVM based }\end{array}$ & $\begin{array}{l}\text { Regres- } \\
\text { sion }\end{array}$ & +++ & +++ & ++ & {$[54]$} \\
\hline $\begin{array}{l}\text { Rnsemble- } \\
\text { SVM based }\end{array}$ & $\begin{array}{l}\text { Regres- } \\
\text { sion }\end{array}$ & +++ & ++ & $+55]$ \\
\hline SVM & sion & ++ & & \\
\hline sion & ++ & + & ++ & \\
\hline
\end{tabular}




\section{Conclusion}

This paper concludes that the usage of machine learning in building energy information applications is growing at a higher rate than we have seen during the last decade. The ensemble and hybrid models have emerged and continue to advance for higher accuracy and better performance. Deep learning models also will bring a tremendous amount of intelligence for better prediction models. This trend has been also reported in other research domains, e.g. biofuels, agriculture, hydrology, and production [56-64].

\section{Acknowledgments}

This publication has been supported by the Project: "Support of research and development activities of the J. Selye University in the field of Digital Slovakia and creative industry" of the Research \& Innovation Operational Programme (ITMS code: NFP313010T504) co-funded by the European Regional Development Fund.

\section{References}

1. Ahmad, T., et al., Supervised based machine learning models for short, medium and long-term energy prediction in distinct building environment. Energy, 2018. 158: p. 17-32.

2. Jiang, Z., R. Lin, and F. Yang, A hybrid machine learning model for electricity consumer categorization using smart meter data. Energies, 2018. 11(9).

3. Kim, S.H., et al., Deep learning based on multi-decomposition for short-term load forecasting. Energies, 2018. 11(12).

4. Laib, O., M.T. Khadir, and L. Mihaylova, Toward efficient energy systems based on natural gas consumption prediction with LSTM Recurrent Neural Networks. Energy, 2019. 177: p. 530-542. 
5. Li, Z., et al., An ANN-based fast building energy consumption prediction method for complex architectural form at the early design stage. Building Simulation, 2019.

6. Liu, L. and W. Ran, Research on supply chain partner selection method based on BP neural network. Neural Computing and Applications, 2019.

7. Protić, M., F. Fathurrahman, and M. Raos, Modelling energy consumption of the republic of Serbia using linear regression and artificial neural network technique. Tehnicki Vjesnik, 2019. 26(1): p. 135-141.

8. Rahman, A. and A.D. Smith, Predicting heating demand and sizing a stratified thermal storage tank using deep learning algorithms. Applied Energy, 2018. 228: p. 108-121.

9. Seyedzadeh, S., et al., Machine learning for estimation of building energy consumption and performance: a review. Visualization in Engineering, 2018. 6(1).

10. Mosavi, A., P. Ozturk, and K.W. Chau, Flood prediction using machine learning models: Literature review. Water (Switzerland), 2018. 10(11).

11. Mosavi, A. and T. Rabczuk, Learning and intelligent optimization for material design innovation, D.E. Kvasov, et al., Editors. 2017, Springer Verlag. p. 358363.

12. Mosavi, A., T. Rabczuk, and A.R. Varkonyi-Koczy, Reviewing the novel machine learning tools for materials design, D. Luca, L. Sirghi, and C. Costin, Editors. 2018, Springer Verlag. p. 50-58.

13. Mosavi, A., et al., State of the art of machine learning models in energy systems, a systematic review. Energies, 2019. 12(7). 
14. Mosavi, A., et al., Prediction of multi-inputs bubble column reactor using a novel hybrid model of computational fluid dynamics and machine learning. Engineering Applications of Computational Fluid Mechanics, 2019. 13(1): p. 482-492.

15. Mosavi, A. and A.R. Varkonyi-Koczy, Integration of machine learning and optimization for robot learning, R. Jablonski and R. Szewczyk, Editors. 2017, Springer Verlag. p. 349-355.

16. Nosratabadi, S., et al., Sustainable business models: A review. Sustainability (Switzerland), 2019. 11(6).

17. Qasem, S.N., et al., Estimating daily dew point temperature using machine learning algorithms. Water (Switzerland), 2019. 11(3).

18. Rezakazemi, M., A. Mosavi, and S. Shirazian, ANFIS pattern for molecular membranes separation optimization. Journal of Molecular Liquids, 2019. 274: p. $470-476$.

19. Riahi-Madvar, H., et al., Comparative analysis of soft computing techniques $R B F, M L P$, and ANFIS with MLR and MNLR for predicting grade-control scour hole geometry. Engineering Applications of Computational Fluid Mechanics, 2019. 13(1): p. 529-550.

20. Shabani, S.; Samadianfard, S.; Taghi Sattari, M.; Shamshirband, S.; Mosavi, A.; Kmet, T.; R. Várkonyi-Kóczy, A. Modeling Daily Pan Evaporation in Humid Cli-mates Using Gaussian Process Regression. Preprints 2019, 2019070351 (doi: 10.20944/preprints201907.0351.v1).

21. S Shamshirband, S.; Hadipoor, M.; Baghban, A.; Mosavi, A.; Bukor J.; Annamaria R. Varkonyi-Koczy, Developing an ANFIS-PSO Model to predict mercury emissions in Combustion Flue Gases. Preprints 2019, 2019070165 (doi: 10.20944/preprints201907.0165.v1). 
22. Shamshirband, S., et al., Ensemble models with uncertainty analysis for multiday ahead forecasting of chlorophyll a concentration in coastal waters. Engineering Applications of Computational Fluid Mechanics, 2019. 13(1): p. 91-101.

23. Shamshirband, S., A. Mosavi, and T. Rabczuk, Particle swarm optimization model to predict scour depth around bridge pier. arXiv preprint arXiv:1906.08863, 2019.

24. Taherei Ghazvinei, P., et al., Sugarcane growth prediction based on meteorological parameters using extreme learning machine and artificial neural network. Engineering Applications of Computational Fluid Mechanics, 2018. 12(1): p. 738-749.

25. Torabi, M., et al., A Hybrid clustering and classification technique for forecasting short-term energy consumption. Environmental Progress and Sustainable Energy, 2019. 38(1): p. 66-76.

26. Torabi, M., et al., A Hybrid Machine Learning Approach for Daily Prediction of Solar Radiation, in Lecture Notes in Networks and Systems. 2019, Springer. p. 266-274.

27. Aram, F., et al., Design and validation of a computational program for analysing mental maps: Aram mental map analyzer. Sustainability (Switzerland), 2019. 11(14).

28. Asadi, E., et al., Groundwater Quality Assessment for Drinking and Agricultural Purposes in Tabriz Aquifer, Iran. 2019.

29. Asghar, M. Z.; Subhan, F.; Imran, M.; Kundi, F.M.; Shamshirband, S.; Mosavi, A.; Csiba, P.; R. Várkonyi-Kóczy, A. Performance Evaluation of Supervised Machine Learning Techniques for Efficient Detection of Emotions from Online Content. Pre-prints 2019, 2019080019 (doi: 10.20944/preprints201908.0019.v1). 
30. Bemani, A.; Baghban, A.; Shamshirband, S.; Mosavi, A.; Csiba, P.; VárkonyiKóczy, A.R. Applying ANN, ANFIS, and LSSVM Models for Estimation of Acid Sol-vent Solubility in Supercritical CO2. Preprints 2019, 2019060055 (doi: 10.20944/preprints201906.0055.v2).

31. Choubin, B., et al., Snow avalanche hazard prediction using machine learning methods. Journal of Hydrology, 2019. 577.

32. Choubin, B., et al., An ensemble prediction of flood susceptibility using multivariate discriminant analysis, classification and regression trees, and support vector machines. Science of the Total Environment, 2019. 651: p. 2087-2096.

33. Dehghani, M., et al., Prediction of hydropower generation using Grey wolf optimization adaptive neuro-fuzzy inference system. Energies, 2019. 12(2).

34. Dineva, A., et al., Review of soft computing models in design and control of rotating electrical machines. Energies, 2019. 12(6).

35. Dineva, A., et al., Multi-Label Classification for Fault Diagnosis of Rotating Electrical Machines. 2019.

36. Farzaneh-Gord, M., et al., Numerical simulation of pressure pulsation effects of a snubber in a CNG station for increasing measurement accuracy. Engineering Applications of Computational Fluid Mechanics, 2019. 13(1): p. 642-663.

37. Ghalandari, M., et al., Investigation of submerged structures' flexibility on sloshing frequency using a boundary element method and finite element analysis. Engineering Applications of Computational Fluid Mechanics, 2019. 13(1): p. 519-528. 
38. Ghalandari, M., et al., Flutter speed estimation using presented differential quadrature method formulation. Engineering Applications of Computational Fluid Mechanics, 2019. 13(1): p. 804-810.

39. Karballaeezadeh, N., et al., Prediction of remaining service life of pavement using an optimized support vector machine (case study of Semnan-Firuzkuh road). Engineering Applications of Computational Fluid Mechanics, 2019. 13(1): p. 188-198.

40. Menad, N.A., et al., Modeling temperature dependency of oil - water relative permeability in thermal enhanced oil recovery processes using group method of data handling and gene expression programming. Engineering Applications of Computational Fluid Mechanics, 2019. 13(1): p. 724-743.

41. Mohammadzadeh, S., et al., Prediction of Compression Index of Fine-Grained Soils Using a Gene Expression Programming Model. Infrastructures, 2019. 4(2): p. 26.

42. Mosavi, A. and M. Edalatifar, A Hybrid Neuro-Fuzzy Algorithm for Prediction of Reference Evapotranspiration, in Lecture Notes in Networks and Systems. 2019, Springer. p. 235-243.

43. Mosavi, A., A. Lopez, and A.R. Varkonyi-Koczy, Industrial applications of big data: State of the art survey, D. Luca, L. Sirghi, and C. Costin, Editors. 2018, Springer Verlag. p. 225-232.

44. Osborne, P.E. and T. Alvares-Sanches, Quantifying how landscape composition and configuration affect urban land surface temperatures using machine learning and neutral landscapes. Computers, Environment and Urban Systems, 2019. 76: p. 80-90.

45. Djenouri, D., et al., Machine learning for smart building applications: Review and taxonomy. ACM Computing Surveys, 2019. 52(2). 
46. Hribar, R., et al., A comparison of models for forecasting the residential natural gas demand of an urban area. Energy, 2019: p. 511-522.

47. Singaravel, S., J. Suykens, and P. Geyer, Deep-learning neural-network architectures and methods: Using component-based models in buildingdesign energy prediction. Advanced Engineering Informatics, 2018. 38: p. 8190.

48. Ahmad, T., et al., A comprehensive overview on the data driven and large scale based approaches for forecasting of building energy demand: A review. Energy and Buildings, 2018. 165: p. 301-320.

49. Raza, M.Q., M. Nadarajah, and C. Ekanayake, Demand forecast of PV integrated bioclimatic buildings using ensemble framework. Applied Energy, 2017. 208: p. 1626-1638.

50. Sharif, S.A. and A. Hammad, Developing surrogate ANN for selecting nearoptimal building energy renovation methods considering energy consumption, LCC and LCA. Journal of Building Engineering, 2019. 25.

51. Chammas, M., A. Makhoul, and J. Demerjian, An efficient data model for energy prediction using wireless sensors. Computers and Electrical Engineering, 2019. 76: p. 249-257.

52. Fenza, G., M. Gallo, and V. Loia, Drift-aware methodology for anomaly detection in smart grid. IEEE Access, 2019. 7: p. 9645-9657.

53. Almalaq, A. and J.J. Zhang, Evolutionary Deep Learning-Based Energy Consumption Prediction for Buildings. IEEE Access, 2019. 7: p. 1520-1531.

54. Chou, J.S. and D.S. Tran, Forecasting energy consumption time series using machine learning techniques based on usage patterns of residential householders. Energy, 2018: p. 709-726. 
55. Koschwitz, D., J. Frisch, and C. van Treeck, Data-driven heating and cooling load predictions for non-residential buildings based on support vector machine regression and NARX Recurrent Neural Network: A comparative study on district scale. Energy, 2018. 165: p. 134-142.

56. Ardabili, S., Mosavi, A., Mahmoudi, Mesri Gundoshmian, T, Nosratabadi, S., Var-konyi-Koczy, A., Modelling temperature variation of mushroom growing hall us-ing artificial neural networks, Preprints 2019.

57. Mesri Gundoshmian, T., Ardabili, S., Mosavi, A., Varkonyi-Koczy, A., Prediction of combine harvester performance using hybrid machine learning modeling and re-sponse surface methodology, Preprints 2019.

58. Ardabili, S., Mosavi, A., Varkonyi-Koczy, A., Systematic review of deep learning and machine learning models in biofuels research, Preprints 2019.

59. Ardabili, S., Mosavi, A., Varkonyi-Koczy, A., Advances in machine learning model-ing reviewing hybrid and ensemble methods, Preprints 2019.

60. Ardabili, S., Mosavi, A., Varkonyi-Koczy, A., Building Energy information: demand and consumption prediction with Machine Learning models for sustainable and smart cities, Preprints 2019.

61. Faizollahzadeh ardabili, S.; Mosavi, A.; Dehghani, M.; R. Várkonyi-Kóczy, A. Deep Learning and Machine Learning in Hydrological Processes, Climate Change and Earth Systems: A Systematic Review. Preprints 2019, 2019080166 (doi: 10.20944/preprints201908.0166.v1).

62. Mohammadzadeh S., D.; Karballaeezadeh, N.; Mohemmi, M.; Mosavi, A.; R. Várkonyi-Kóczy, A. Urban Train Soil-Structure Interaction Modeling and Analysis. Preprints 2019, $2019080162 \quad$ (doi: 10.20944/preprints201908.0162.v1). 
63. Mosavi, A.; Faizollahzadeh ardabili, S.; R. Várkonyi-Kóczy, A. List of Deep Learning Models. Preprints 2019, $2019080152 \quad$ (doi: 10.20944/preprints201908.0152.v1).

64. Nosratabadi, S.; Mosavi, A.; Keivani, R.; Faizollahzadeh ardabili, S.; Aram, F. State of the Art Survey of Deep Learning and Machine Learning Models for Smart Cities and Urban Sustainability. Preprints 2019, 2019080154 (doi: 10.20944/preprints201908.0154.v1). 